\title{
Modulation of Saharan dust export by the North African dipole
}

\author{
S. Rodríguez ${ }^{1}$, E. Cuevas ${ }^{1}$, J. M. Prospero ${ }^{2}$, A. Alastuey ${ }^{3}$, X. Querol ${ }^{3}$, J. López-Solano ${ }^{1}$, M. I. García ${ }^{1,4}$, and \\ S. Alonso-Pérez ${ }^{1,3,5}$ \\ ${ }^{1}$ Izaña Atmospheric Research Centre, AEMET, Santa Cruz de Tenerife, Spain \\ ${ }^{2}$ Rosenstiel School of Marine and Atmospheric Science, University of Miami, Miami, Florida, USA \\ ${ }^{3}$ Institute of Environmental Assessment and Water Research, CSIC, Barcelona, Spain \\ ${ }^{4}$ Department of Chemistry (T.U. Analytical Chemistry), Faculty of Science, University of La Laguna, Tenerife, Spain \\ ${ }^{5}$ European University of the Canaries, Laureate International Universities, La Orotava, Tenerife, Spain
}

Correspondence to: S. Rodríguez (srodriguezg@aemet.es)

Received: 16 September 2014 - Published in Atmos. Chem. Phys. Discuss.: 24 October 2014

Revised: 24 April 2015 - Accepted: 23 June 2015 - Published: 10 July 2015

\begin{abstract}
We have studied the relationship between the longterm interannual variability in large-scale meteorology in western North Africa - the largest and most active dust source worldwide - and Saharan dust export in summer, when enhanced dust mobilization in the hyper-arid Sahara results in maximum dust impacts throughout the North Atlantic. We address this issue by analyzing 28 years (19872014) of summer averaged dust concentrations at the highaltitude Izaña observatory ( $\sim 2400 \mathrm{~m}$ a.s.l.) on Tenerife, and satellite and meteorological reanalysis data. The summer meteorological scenario in North Africa (aloft $850 \mathrm{hPa}$ ) is characterized by a high over the the subtropical Sahara and a low over the tropics linked to the monsoon. We measured the variability of this high-low dipole-like pattern in terms of the North African dipole intensity (NAFDI): the difference of geopotential height anomalies averaged over the subtropics $\left(30-32^{\circ} \mathrm{N}\right.$, Morocco) and the tropics $\left(10-13^{\circ} \mathrm{N}\right.$, Bamako region) close to the Atlantic coast (at $5-8^{\circ} \mathrm{W}$ ). We focused on the $700 \mathrm{hPa}$ standard level due to dust export off the coast of North Africa tending to occur between 1 and $5 \mathrm{~km}$ a.s.l. Variability in the NAFDI is associated with displacements of the North African anticyclone over the Sahara and this has implications for wind and dust export. The correlations we found between the 1987-2014 summer mean of NAFDI with dust at Izaña, satellite dust observations and meteorological reanalysis data indicate that increases in the NAFDI (i) result in higher wind speeds at the north of the Inter-Tropical Convergence Zone that are associated with enhanced dust export over the subtropical North Atlantic, (ii) influence the longterm variability of the size distribution of exported dust par-
\end{abstract}

ticles (increasing the load of coarse dust) and (iii) are associated with enhanced rains in the tropical and northern shifts of the tropical rain band that may affect the southern Sahel. Interannual variability in NAFDI is also connected to spatial distribution of dust over the North Atlantic; high NAFDI summers are associated with major dust export (linked to winds) in the subtropics and minor dust loads in the tropics (linked to higher rainfall), and vice versa. The evolution of the summer NAFDI values since 1950 to the present day shows connections to climatic variability (through the Sahelian drought, ENSO (El Niño-Southern Oscillation) and winds) that have implications for dust export paths. Efforts to anticipate how dust export may evolve in future decades will require a better understanding of how the large-scale meteorological systems represented by the NAFD will evolve.

\section{Introduction}

Desert dust aerosols influence global climate by scattering and absorbing radiation (Forster et al., 2007), influencing rainfall (Creamean et al., 2013), and also by modulating ocean-atmosphere $\mathrm{CO}_{2}$ exchange through the deposition of dust that supplies iron, a micronutrient for marine biota (Jickells et al., 2005). Ice core records show increased dust activity during glacial periods when $\mathrm{CO}_{2}$ was low (MartínezGarcía et al., 2009). Dense dust hazes often occur between tropical and middle latitudes over the North Atlantic (Tanaka and Chiba, 2006), with implications also for air quality (Rodríguez et al., 2001; Pérez et al., 2008; Mallone et al., 2011; 
Díaz et al., 2012). Consequently, there is considerable interest in climate variability, the global distribution of dust (Adams et al., 2012; Ginoux et al., 2012) and dust microphysical properties including particle size, which modulates dust impacts (Mahowald et al., 2014), e.g., the interaction with radiation (Otto et al., 2007), iron solubility and supply to the ocean (Baker and Jickells, 2006), its role as cloud and ice nuclei (Welti et al., 2009), and health effects due to dust exposure (Pérez et al., 2008, 2014; Mallone et al., 2011; Díaz et al., 2012). During atmospheric transport, dust is removed by precipitation and by dry deposition, the latter a process that is strongly size dependent. Dust size variability is observed over timescales of individual dust events ( days) (Ryder et al., 2013) and in ice cores, over thousands of years, linked to changes in wind speeds, transport pathways and dust sources attributed to climate variability (Delmonte et al., 2004).

North Africa is the largest and most active dust source in the world (Ginoux et al., 2004, 2012; Huneeus et al., 2011). Dust mobilization experiences a marked seasonality. In winter, sources located in the southern Sahara and the Sahel $\left(<20^{\circ} \mathrm{N}\right)$ are especially active, linked to northeasterly dry (Harmattan - trade) winds that prompt dust export across the North African tropical coast $\left(<15^{\circ} \mathrm{N}\right)$ (Engelstaedter and Washington, 2007; Haywood et al., 2008; Menut et al., 2009; Marticorena et al., 2010). In summer, the northeasterly trade winds and the Inter-Tropical Convergence Zone (ITCZ) shift northward, enhancing emissions from Saharan sources and increasing dust export at subtropical latitudes $\left(20-30^{\circ} \mathrm{N}\right)$; concurrently the northward shift in the monsoon rain band to the southern Sahel tends to decrease Sahelian dust emissions (Engelstaedter and Washington, 2007; Knippertz and Todd, 2010; Ashpole and Washington, 2013, and references therein).

There is a major scientific interest in understanding the links between long-term variability in North African dust export and climate. Dust sources in part of the Sahel have a hydrological nature (Ginoux et al., 2012); their emissions are affected by the summer variability in rainfalls and also by the North Atlantic Oscillation in winter, and this has had consequences for dust impacts on the tropical North Atlantic detected during, at least, four decades (Prospero and Lamb, 2003; Chiapello et al., 2005). In addition, the increase in commercial agriculture over the last two centuries coupled with droughts has had an impact on Sahelian dust emissions (Mulitza et al., 2010). In contrast, the Sahara is a hyper-arid environment $\left(<200 \mathrm{~mm} \mathrm{yr}^{-1}\right)$ where natural nonhydrological dust sources (i.e., not associated with annual hydrological cycles) prevail (Ginoux et al., 2012), and dust emission variability is mainly controlled by winds (Engelstaedter and Washington, 2007; Ridley et al., 2014). A conceptual model explaining interannual variability in Saharan dust export has been proposed for the winter (e.g., North Atlantic Oscillation by Ginoux et al., 2004, and Chiapello et al., 2005), but not for summertime, when the highest dust emis- sions occur in North Africa due to the enhanced activation of the subtropical Saharan sources (Prospero and Lamb, 2003; Ginoux et al., 2004; Chiapello et al., 2005; Tanaka and Chiba, 2006; Engelstaedter and Washington, 2007; Mulitza et al., 2010; Knippertz and Todd, 2012; Ridley et al., 2014). Doherty et al. (2008) found that the trans-Atlantic dust transport of North African dust to the Caribbean is influenced by displacements in the Azores and Hawaiian anticyclones. In this study we have focused on the links between North African meteorology and dust export.

Starting in 1987 we have measured aerosols at the Izaña Global Atmospheric Watch (GAW) World Meteorological Organization (WMO) high-mountain observatory $\left(28^{\circ} 18^{\prime} \mathrm{N}\right.$, $16^{\circ} 29^{\prime} \mathrm{E}$; $2367 \mathrm{~m}$ a.s.l.) on Tenerife, which frequently lies under the main path of the high-altitude Saharan dust outbreaks. At night, when mountain upslope winds cease, Izaña is within the free troposphere airflows, frequently within the dust-laden Saharan air layer (SAL), which in summer is typically located at altitudes between $\approx 1$ and $5 \mathrm{kma}$ a.s.l. (Adams et al., 2012; Nicholson, 2013; Tsamalis et al., 2013). Here we report on long-term measurements of summertime concentrations of total dust (dust $\mathrm{T}$ ) (1987-2014) and of dust particles $<2.5 \mu \mathrm{m}$ (dust 2.5 ) (2002-2014). Our 28-year observation shows that there is a significant interannual variability in Saharan dust export in summer. Our research focuses on one key question: "What is the relationship between long-term interannual variability in Saharan dust export in summer and large-scale meteorology in North Africa?" To address this issue, we also used (i) the UV Aerosol Index determined by the Total Ozone Mapping Spectrometer and Ozone Monitor Instrument satellite-borne spectrometers (Herman et al., 1997) for studying long-term and interannual spatial distribution of dust and (ii) gridded meteorological National Center for Environmental Prediction/National Center for Atmospheric Research (NCEP/NCAR) re-analysis data (Kalnay et al., 1996) for studying the variability of large-scale meteorological processes.

In this article, we first perform a brief description of the typical meteorological scenario in western North Africa in the summertime. Then, the concept of the North African dipole is introduced as an approach to characterizing how variability in large-scale meteorology may influence Saharan dust export. We then assessed how the long-term variability in the intensity of the North African dipole has influenced long-term Saharan dust export to the free troposphere during 28 years and particle size distribution during 13 years. Finally, we assess whether the North African dipole intensity can be used to connect Saharan dust export to climate variability. Here we present connections between dust export and large-scale meteorology; further studies will be necessary for understanding the involved meteorological and dust processes. 


\section{Methods}

\subsection{In situ dust measurements}

We used in situ dust concentration data recorded between 1987 and 2014 at Izaña observatory. Here we present a brief description of the methods; details are included in Sect. S1 of the Supplement.

Dust concentrations were obtained by chemical analysis of aerosol samples collected on filters at the flow rate of $30 \mathrm{~m}^{3} \mathrm{~h}^{-1}$. Throughout the almost three decades of observations, several analytical methods have been used for determining soluble species $\left(\mathrm{SO}_{4}^{=}, \mathrm{NO}_{3}^{-}\right.$, and $\mathrm{NH}_{4}^{+}$by ion chromatography and colorimetry), organic and elemental carbon (by TOT), elemental composition (INAA, IPC-AES and IPCMS) and the content of dust (by the "weight of the ash residue after $14 \mathrm{~h}$ heating at $500^{\circ} \mathrm{C}$ " method and by using the elemental composition data) in the aerosol samples; details of these methods and their use throughout the measurement period are included in Table S1 of the Supplement. In order to facilitate data comparison with other studies, dust concentrations are reported to mean pressure at sea level $(1013 \mathrm{hPa})$ and normalized in such a way that aluminum accounts for $8 \%$ dust (mean content of $\mathrm{Al}$ in soils). Here we report on dust concentrations in two size fractions: concentrations of total dust (dust ${ }_{\mathrm{T}}$ ) from 1987 to 2014 and of dust particles with an aerodynamic diameter $\leq 2.5 \mu \mathrm{m}$ (dust 2.5 ) from 2002 to 2014 (Rodríguez et al., 2012).

Dust concentrations were also calculated with a secondary complementary method based on number size distribution measurements ( 0.5 to $20 \mu \mathrm{m}$ ) performed with an optical particle counter and an aerodynamic particle sizer. These data were used for determining the aerosol volume concentrations and converting them to bulk aerosol mass concentrations using standard methods (Rodríguez et al., 2012). The good agreement (high linearity and low mean bias, 3-8\%) between these two methods (based on chemical analysis and on size distributions) is due to the very low aerosol volume concentrations in the free troposphere during no dust events (typically $<1$ to $<3 \mu \mathrm{g} \mathrm{m}^{-3}$; Rodríguez et al., 2009) and to the fact that the aerosol volume concentrations during dust events are by far dominated by dust, as evidenced by the chemical analysis (Rodríguez et al., 2011) and the ochre color of the aerosol samples (Fig. 1b).

These two dust databases (based on chemical and size distribution methods) were used to assess the consistency of the observed year-to-year variability of dust. During the whole measurement period (25 July 1987-31 December 2014, excluding the non-measurement period 11 October 1999-13 February 2002), dust concentration records are available for 8001 days, which leads to a data availability of $87.3 \%$. This record of aerosol dust concentration is among the longest in the world (after Barbados, started in 1965, Miami, 1972, and American Samoa, 1983) and probably the longest in the free
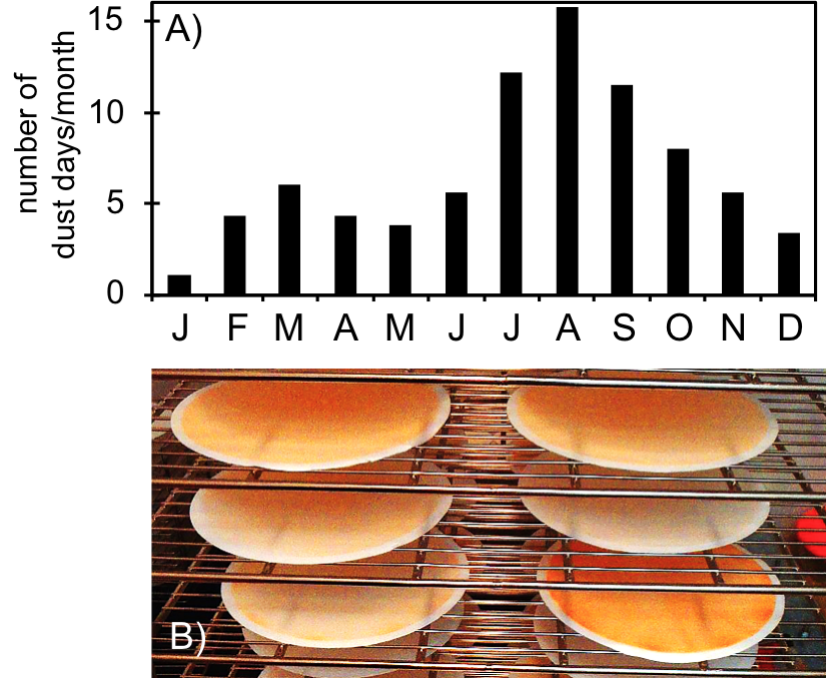

Figure 1. Saharan dust observations in Izaña. (a) Frequency of dust events $\left(>10 \mu \mathrm{g} \mathrm{m}^{-3}\right)$ in Izaña in the period 1987-2014. (b) Batch of filters with aerosol samples collected at Izaña for illustrating their typical ochre color due to dust.

troposphere and in several size fractions downwind of a dust large source (Rodríguez et al., 2012).

\subsection{Satellite dust observations}

We used UV Aerosol Index (AI) data from the Total Ozone Mapping Spectrometer - TOMS - (1979-2001) and from the Ozone Monitor Instrument - OMI - (2005-2014) spectrometers onboard satellites Nimbus 7 (TOMS 1979-1993), Earth Probe (TOMS 1996-2001) and Aura (OMI 2005-2014) to study the spatial and temporal variability of dust. Because of the UV absorption by some minerals (e.g., hematite, goethite), AI has been widely used in dust studies. This is a semi-quantitative parameter; AI values $>1$ are considered representative of an important dust load and the frequency of daily AI values $>1$ has been used for dust climatology (Prospero et al., 2002). In North Africa, the AI signal at the north of the summer tropical rain band is due to dust, whereas biomass burning aerosols transported from southern Africa contribute to the AI signal at the south of the tropical rain band (Prospero et al., 2002). We only analyzed and interpreted the variability in the frequency of daily $\mathrm{AI}>1$ at the north of the summer tropical rain band. The following data were used:

- Level 3 TOMS data of the period 1979-2001. TOMS data for the period 2002-2005 were not used due to calibration problems (http://disc.sci.gsfc.nasa.gov/guides/ legacy-guides/tomsl3_dataset.gd.shtml).

- Level 3 OMI data of the period 2005-2014. Although this instrument has experienced the so-called "row anomalies" since 2007 (http://www.knmi.nl/omi/ 
research/product/rowanomaly-background.php), the affected data are not included in the Level 3 data sets (http://disc.sci.gsfc.nasa.gov/Aura/data-holdings/OMI/ index.shtml\#info).

Level 3 daily AI data of TOMS and OMI of summer (August) were downloaded from the Giovanni online data system of the NASA Goddard Earth Sciences Data and Information Services Center (GES DISC) (http://disc.sci.gsfc.nasa.gov/). The consistency of the TOMS and OMI AI data set has already been shown ( $\mathrm{Li}$ et al., 2009). Consistency between TOMS, OMI and our in situ dust measurements is analyzed in Sect. S3 of the Supplement (including Figs. S4 and S5).

\subsection{Meteorological reanalysis data}

We used gridded meteorological National Center for Environmental Prediction/National Center for Atmospheric Research (NCEP/NCAR) re-analysis data (Kalnay et al., 1996) to study the relationship between dust variability and largescale meteorological processes in summer (August). This analysis included geopotential heights, winds and rains used in Eq. (1) (shown below) and Figs. 2, 4 and 9.

\subsection{Summer dust season}

At Izaña, the summer dust season (impacts of the SAL) typically starts in the second half of July and ends at the beginning of September (Sect. S2 of the Supplement). The maximum frequency of dust events occurs in August (52\% of the August days as average; Fig. 1). This month is of high interest given that (i) the ITCZ is shifted to the north and consequently (ii) the SAL is exported at the northernmost latitude (as evidence of the highest frequency of dust impacts at Izaña; Tsamalis et al., 2013) and the maximum rainfall occurs in tropical North Africa (Nicholson, 2009). For this reason, we used the August dust averages for studying summer long-term dust evolution in the boreal subtropics (Fig. 1a). The study of the central month (August) of the summer dust season (excluding July and September) allows one to characterize long-term evolution in terms of intensity of dust export, avoiding the variability that could be linked to (i) shifts in the beginning (July) or end (September) dates of the dust season or (ii) variability in the location of the ITCZ from July to September. Our data analysis shows that the July to September dust average is dominated by the dust events occurring in August (Fig. S3 of the Supplement). In August 1987-2014, daily dust data were available during 761 days, i.e., a data availability of $94 \%$ (excluding the no-measurement period 11 October 1999-13 February 2002). In this study we analyze 1987-2014 time series of in situ dust concentration at Izaña (determined by chemical methods) averaged on all (dust and no-dust) days of August (shown in Fig. 3a and analyzed below). We refer to August as summer. Results are presented in Sect. 4; additional analysis is presented in Sect. S3 of the Supplement.

\section{North African summer meteorological scenario}

The meteorological scenario throughout western North Africa is influenced by the high pressures typical of the subtropical deserts and the so-called western African monsoon (Lafore et al., 2010). Additionally, the formation of the summer Saharan heat low (Lavaysse et al., 2009) in the central western Sahara also has implications for meteorological processes, not only related to the development of the wet western African monsoon season in tropical North Africa (Lafore et al., 2010), but also to mobilization, upward transport and export of dust to the North Atlantic at subtropical latitudes (Jones et al., 2003; Flamant et al., 2007; Knippertz and Todd, 2010).

In summer, the vertical structure of the atmosphere over the Sahara is characterized by the Saharan heat low at low levels (surface to $925 \mathrm{~Pa}$ standard level at $\sim 20^{\circ} \mathrm{N}$ ) with a confluence of surface "northern dry desert Harmattan" and "southern humid monsoon" winds at its southern margin (Nicholson, 2013) in the so-called ITCZ, which in the central western Sahara occurs between 18 and $20^{\circ} \mathrm{N}$ (Lafore et al., 2010; Pospichal et al., 2010; ITCZ also known as the Inter-Tropical Discontinuity - ITD). Monsoon rainfalls occur at southern latitudes $\left(<15^{\circ} \mathrm{N}\right)$, in a region we will refer to as the rain band (Nicholson, 2009). The Saharan heat low, as a shallow hot depression, enhances subsidence processes due to compensatory downward movement in upper levels (Spengler and Smith, 2008; Canut et al., 2010). The African Easterly Jet (AEJ) forms at altitudes between 2 and $6 \mathrm{~km}$ between 15 and $20^{\circ} \mathrm{N}$ due to the thermal wind in the baroclinic zone between the "northern hot desert air" and the "cool monsoonal southern airflow" (Nicholson, 2009, 2013).

Emissions, upward transport and export of dust to the North Atlantic occur in this summer scenario. Dust emission processes occur in a range of scales (Knippertz and Todd, 2012) from (i) synoptic scale (e.g., Harmattan trade winds, African easterly waves; Jones et al., 2003; Knippertz and Todd, 2010), through (ii) strong winds, convergence and high turbulence associated with the ITCZ (Flamant et al., 2007; Ashpole and Washington, 2013), low-level jets (Knippertz, 2008; Fiedler et al., 2013) and cold pools of mesoscale dry convective systems (particularly over the Sahel; Engelstaedter and Washington, 2007; Lavaysse et al., 2010a, and references therein) including "haboob" storms (Marsham et al., 2008), to (iii) microscale dust devils and dusty plumes (Allen and Washington, 2013). As a consequence of convergence processes close to the ITCZ (Ashpole and Washington, 2013) and because of the convective boundary layer, huge amounts of dust are lifted up to $\sim 5 \mathrm{~km}$ altitude (Cuesta et al., 2009; Guirado et al., 2014). The easterly subtropical circulation at the south of the North African anticyclone typically present at the altitude of the $700 \mathrm{hPa}$ level and aloft (Font-Tullot, 1950; UK Meteorological Office, 1962), coupled with the divergence linked to the Saharan heat low, and the AEJ (Lavaysse et al., 2010a), expands 
this dry dusty air mass over the North Atlantic free troposphere resulting in the previously described SAL (Prospero and Carlson, 1972; Tsamalis et al., 2013). Off the coast of North Africa, the summer SAL is found at altitudes between 1 and $5 \mathrm{~km}$ (Karyampudi et al., 1999; Immler and Schrems, 2003; Tsamalis et al., 2013; Andrey et al., 2014) due to the westward dust export occurs above the so-called "Atlantic inflow", a layer of cool and stable sea-breeze-like inflow present along the subtropical North African coast (Lafore et al., 2010).

This brief description illustrates how the presence of the dusty SAL over the North Atlantic is the net result of a set of complex and coupled processes that occur in a wide range of scales and that may also involve (i) feedback mechanisms (e.g., radiative, cloud and rain processes triggered by dust; Lau et al., 2009), (ii) interconnections between processes (e.g., influence of the AEJ-convection-monsoon connections on dust described by Hosseinpour and Wilcox, 2014), (iii) variability in dust emissions due to meteorologically driven variability in soil features (Prospero and Lamb, 2003) and (iv) dust microphysical processes (e.g., size-dependent deposition and cloud and radiation interactions; Mahowald et al., 2014).

\section{Results and discussion}

\subsection{The North African dipole}

We aim to find a simple conceptual model for linking longterm variability in Saharan dust export with variability in the large-scale meteorology in western North Africa. Because it resembles a dipole, we will refer to the summer meteorological scenario of North Africa - characterized by high pressure in the subtropical Sahara $\left(27-32^{\circ} \mathrm{N}\right.$ over Algeria; FontTullot, 1950; UK Meteorological Office, 1962) and low pressure in tropical North Africa $\left(<15^{\circ} \mathrm{N}\right)-$ as the North African dipole (NAFD). The NAFD is illustrated in the height of the $850 \mathrm{hPa}$ summer average geopotential in Fig. 2a. The intensity of this dipole can be measured as the difference of the anomalies of the geopotential height over the subtropics and that over the tropics in North Africa. Because summer dust export to the Atlantic occurs between 1 and $5 \mathrm{~km}$ altitude (Prospero and Carlson, 1972; Immler and Schrems, 2003; Tsamalis et al., 2013), with a frequent maximum dust load between 2 and $3 \mathrm{~km}$ (Tesche et al., 2009; Cuevas et al., 2015), we paid special attention to the $700 \mathrm{hPa}$ standard level (Nicholson, 2013) at $5-8^{\circ} \mathrm{W}$ longitude (i.e., close to the Atlantic coast). Thus, in this study we measured the intensity of the NAFD as the difference of the anomalies of the $700 \mathrm{hPa}$ geopotential height averaged averaged over central Morocco $\left(30-32^{\circ} \mathrm{N}, 5-7^{\circ} \mathrm{W}\right)$ and that over the Bamako region in Mali $\left(10-13^{\circ} \mathrm{N}, 6-8^{\circ} \mathrm{W}\right)$ by Eq. (1). Other parameterizations of the NAFD are plausible depending on the study subject. We calculated the NAFD intensity (NAFDI) with Eq. (1) using the average values of the $700 \mathrm{hPa}$ geopotential heights in every month of August (31 days on average) from 1948 to 2014 obtained from the NCEP/NCAR re-analysis (Kalnay et al., 1996):

NAFDI $=\frac{1}{10}\left(\left(\Phi_{\mathrm{Mo}}^{\mathrm{y}}-<\Phi>_{\mathrm{Mo}}\right)-\left(\Phi_{\mathrm{Ba}}^{\mathrm{y}}-<\Phi>_{\mathrm{Ba}}\right)\right)$,

where

- $\Phi_{\text {Mo }}^{\mathrm{y}}$ is the mean geopotential height at $700 \mathrm{hPa}$ averaged in the central Morocco region $\left(30-32^{\circ} \mathrm{N}, 5-7^{\circ} \mathrm{W}\right)$ in August of year " $y$ ".

- $<\Phi>_{\text {Mo }}$ is the mean geopotential height at $700 \mathrm{hPa}$ averaged in the central Morocco region $\left(30-32^{\circ} \mathrm{N}, 5-\right.$ $7^{\circ} \mathrm{W}$ ) averaged in August months from 1948 to 2014.

- $\Phi_{\mathrm{Ba}}^{\mathrm{y}}$ is the mean geopotential height at $700 \mathrm{hPa}$ averaged in the Bamako region $\left(10-13^{\circ} \mathrm{N}, 6-8^{\circ} \mathrm{W}\right)$ in August of year "y".

- $<\Phi>_{\mathrm{Ba}}$ is the mean geopotential height at $700 \mathrm{hPa}$ averaged in the Bamako region $\left(10-13^{\circ} \mathrm{N}, 6-8^{\circ} \mathrm{W}\right)$ averaged in all August months from 1948 to 2014.

- $\frac{1}{10}$ is a scale factor.

The NAFDI (Eq. 1) is a measure of the interannual variability of the dipole intensity and, because of its relationship with the geopotential gradient, it is related to the intensity of the geostrophic North African outflow.

Figure 3 a shows the time series of the summertime NAFDI values from 1987 to 2014, when it showed values between -3.19 and +2.29 . In order to assess how large-scale meteorology changes with NAFDI values, we averaged some meteorological fields during high NAFDI summers and low NAFDI summers (Fig. 4a and c-e). The low NAFDI group includes the summers with the four lowest NAFDI values in the period 1987-2014: 1997 (NAFDI $=-3.19$ ), 1987 (-2.79), $1996(-2.04)$ and 2006 (-1.54). The high NAFDI group includes the summers with the four highest NAFDI values in the period 1987-2014: $2012(+2.29), 2008$ $(+1.01), 2000(+0.83)$ and $1988(\mathrm{NAFDI}=+0.68)$. Only summers for which satellite AI data are available were considered (i.e., the 1993-1995 and 2002-2004 periods were not included in the selection). The spatial distribution of dust was assessed by determining the major dust activity frequency (MDAF) metric: the number of days with AI values $>1$ divided by the total number of days with available AI data in $\%$ (Fig. 4b).

The NAFD is illustrated in Fig. 4a with the mean $700 \mathrm{hPa}$ geopotential height field during summers of low and high NAFDI. The core of the northern Saharan anticyclone is reinforced over the western Atlas Mountains $\left(\sim 30^{\circ} \mathrm{N}\right)$ in high NAFDI summers (Fig. 4a2), whereas it weakens and shifts southward to central Algeria $\left(\sim 28^{\circ} \mathrm{N}\right)$ in low NAFDI summers (Fig. 4a1). Conversely, at the tropical latitude of Bamako $(\sim 12 \mathrm{~N})$, geopotential heights are higher during low 


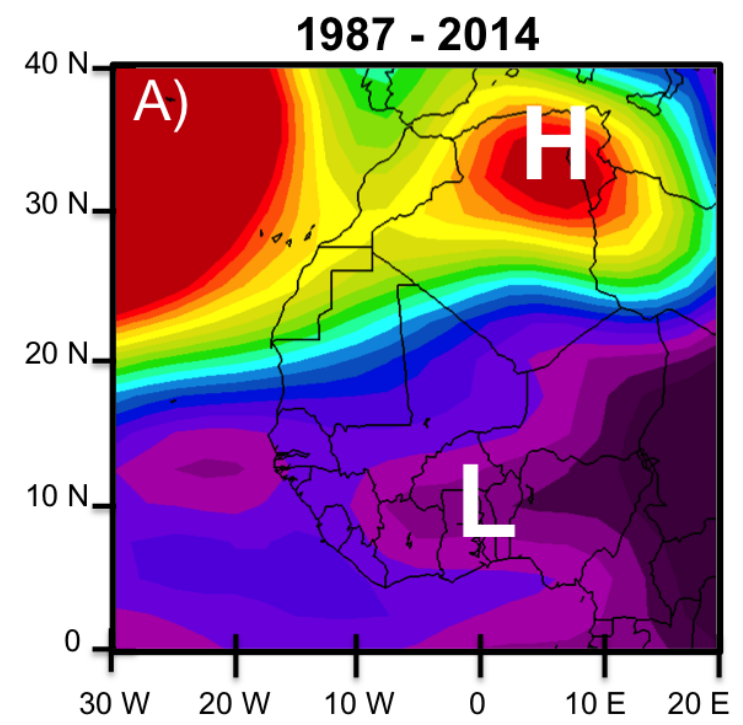

\section{Low NAFDI summers}

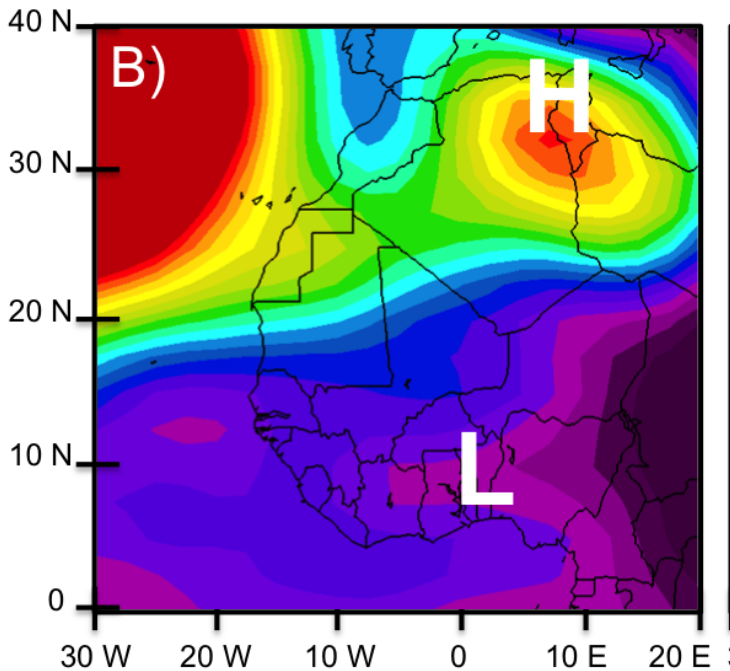

High NAFDI summers

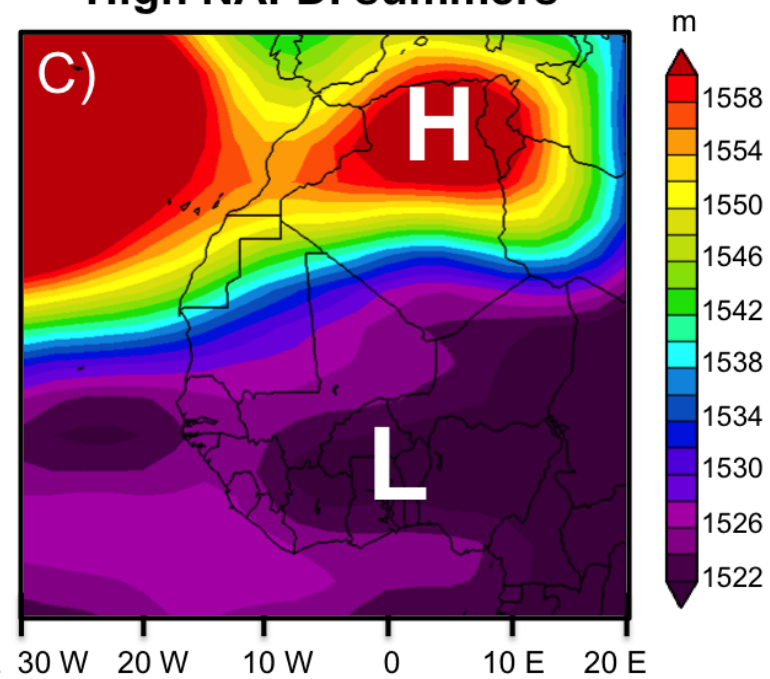

Figure 2. Height of the $850 \mathrm{hPa}$ geopotential over North Africa averaged in (a) all summers (August) from 1987 to 2014 and in summers (August) with (b) low NAFDI values (1987, 1996, 1997 and 2006 have $-2.79,-2.04,-3.19$ and -1.54 , respectively) and (c) high NAFDI values $(1988,2000,2008$ and 2012 have $+0.68,+0.83,+1.01$ and +2.29 , respectively).

NAFDI summers (Fig. 4a1) than during high NAFDI summers (Fig. 4a2).

\subsection{Long-term variability of Saharan dust export}

At Izaña we observe a strong interannual variability in dust concentrations (Fig. 3a). In low dust years - 1987, 1997, 2006 and 2007 - mean concentrations were within the range $17-30 \mu \mathrm{g} \mathrm{m}^{-3}$; in high dust years $-1988,2008$, 2010 and 2012 - the range was $100-140 \mu \mathrm{g} \mathrm{m}^{-3}$. We associate this variability with the spatial variability of meteorological conditions over North Africa, specifically with the NAFD (Fig. 4). The high value of the Pearson correlation coefficient $(r)$ of mean summer dust $\mathrm{T}_{\mathrm{T}}$ at Izaña with the NAFDI from 1987 to 2014 ( $r=0.72$, Fig. 3a) indicates that the dust export is highly sensitive to the dipole intensity (Fig. 5a).

The mean wind fields and precipitation rates are shown along with MDAF for low and high NAFDI summers in Fig. 4. There is a significant variability in the spatial distribution of dust over the North Atlantic in high with respect to low NAFDI periods. Increases in the NAFDI are associated with a strengthening of the zonal (easterly) component of continental trade winds north of the ITCZ in a region we define as the subtropical Saharan Stripe (Fig. 4cd). This strengthening of easterly winds was observed in all standard levels (only shown at 925 and $700 \mathrm{hPa}$ for the sake of brevity) and is associated with a reinforcement of the tropical low to subtropical Saharan high pattern repre- 


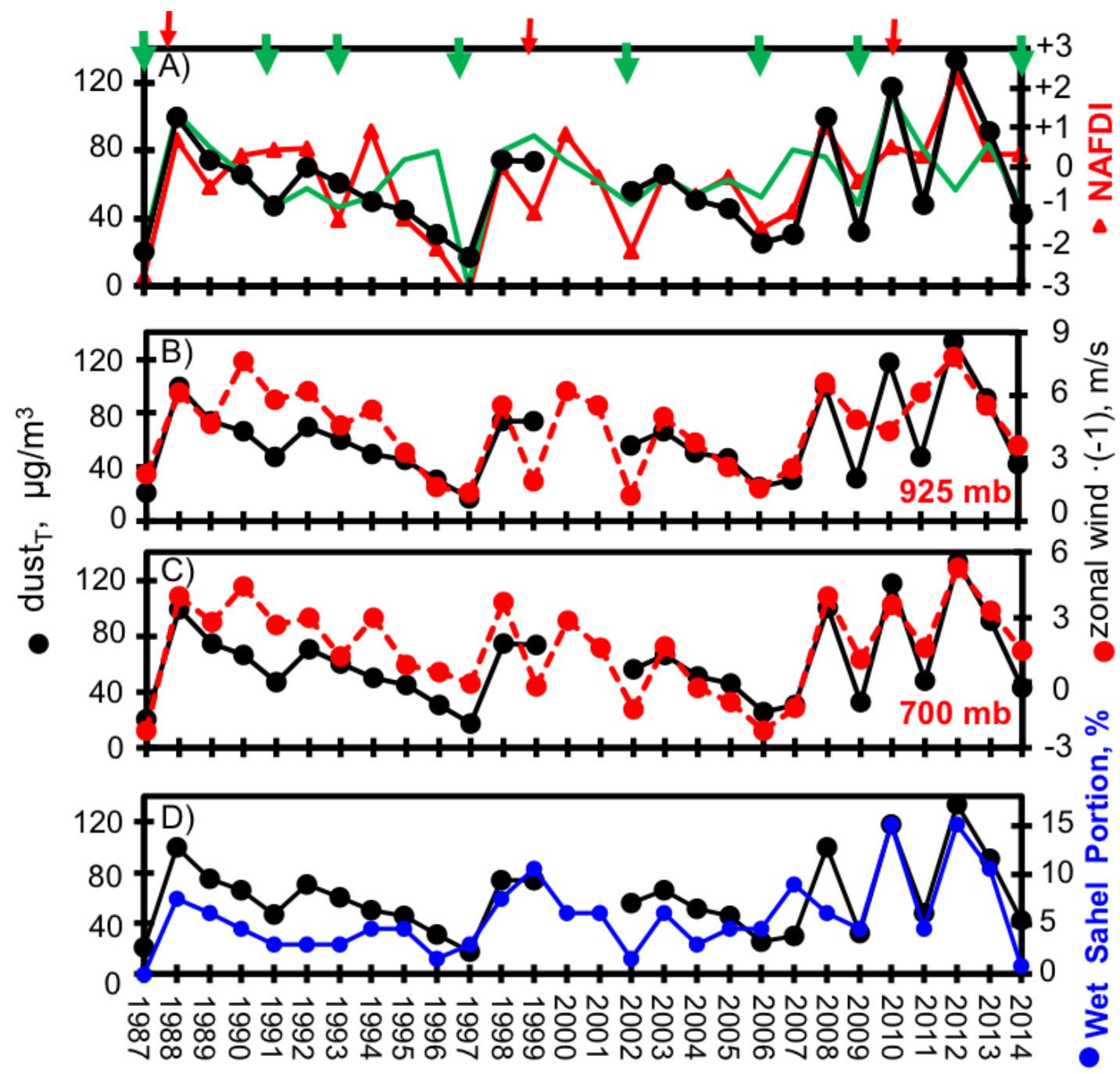

Figure 3. Long-term evolution (1987-2014) of summer dust and meteorology. Summer mean values of dust $\mathrm{T}_{\mathrm{T}}$ concentrations at Izaña (black dot, (a-d), MEI (green line, a), NAFDI (red triangle, a), zonal wind at $925 \mathrm{mb}$ in the subtropical Saharan Stripe $\left(25-28^{\circ} \mathrm{N}, 7^{\circ} \mathrm{W}-2^{\circ} \mathrm{E}\right.$, b), zonal wind at $700 \mathrm{mb}$ averaged in the subtropical Saharan Stripe to Tenerife corridor $\left(25-28^{\circ} \mathrm{N}, 16^{\circ} \mathrm{W}-2^{\circ} \mathrm{E}\right.$, c) and the Wet Sahel Portion (blue dot) from 1987 to 2014. Green and red arrows highlight moderate and intense ENSO and La Niña summers, respectively (http://www.cpc.ncep.noaa.gov).

sented by the NAFD (Fig. $2 b$ and c). The subtropical Saharan Stripe region, which extends from central Algeria to the western Sahara between 24 and $30^{\circ} \mathrm{N}$, includes important dust sources (Prospero et al., 2002; Schepanski et al., 2009; Rodríguez et al., 2011; Ginoux et al., 2012) that clearly exhibit a greater MDAF during summers with high NAFDI (Fig. 4b2). Long-term (1987-2014) summer mean values of NAFDI and of dust $\mathrm{T}_{\mathrm{T}}$ at Izaña are highly correlated with the zonal wind in the subtropical Saharan Stripe $(r=0.6$ to 0.9, Fig. 6a, where negative correlation indicates reinforcement of westward winds). These correlations reflect the net result of a wide range of dust-related processes (emission, vertical transport, advection to the Atlantic and size-dependent deposition during transport). These results are consistent with those of the back-trajectory analysis (Fig. S6 of the Supplement).

The portion of the SAL with a MDAF during more than $40 \%$ of the summertime extends from North Africa to $30^{\circ} \mathrm{W}$ during summers with a low NAFDI (Fig. 4b1); in contrast, the region extends to $55^{\circ} \mathrm{W}$ during high NAFDI summers (Fig. 4b2). In high NAFDI summers, the SAL also expands northward over the subtropical North Atlantic domain (24$35^{\circ} \mathrm{N}, 9-60^{\circ} \mathrm{W}$; Fig. $4 \mathrm{~b}$ ); because of this, the MDAF over the subtropical North Atlantic shows a significant correlation with the NAFDI (1979-2014 $r=0.73$; Fig. 7a) and with dust records at Izaña (Fig. 7b). The positive correlation of NAFDI with the MDAF in the North Atlantic subtropical band (24$35^{\circ} \mathrm{N}$, Fig. $6 \mathrm{~b}$ ) points to an association between summer-to- 


\section{Low NAFDI summers}
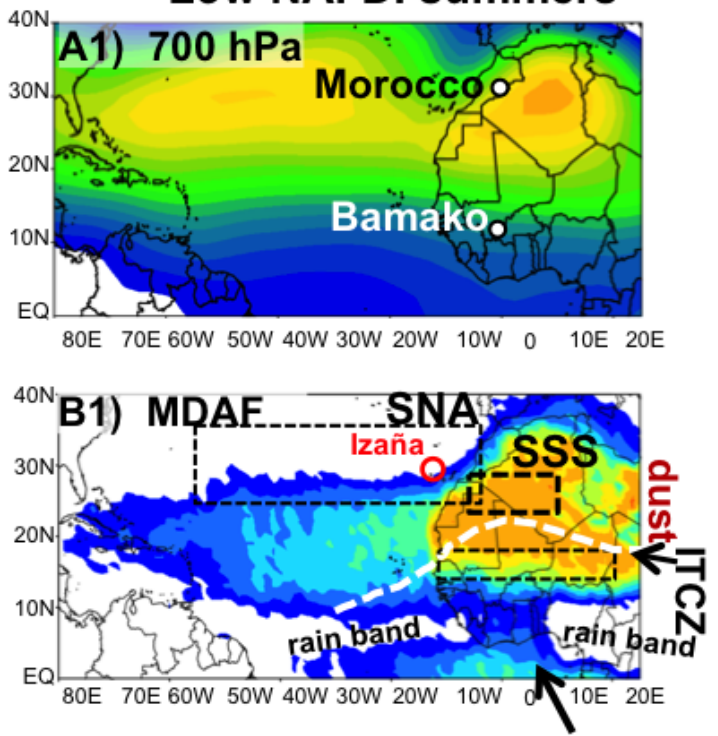

biomass burning aerosols
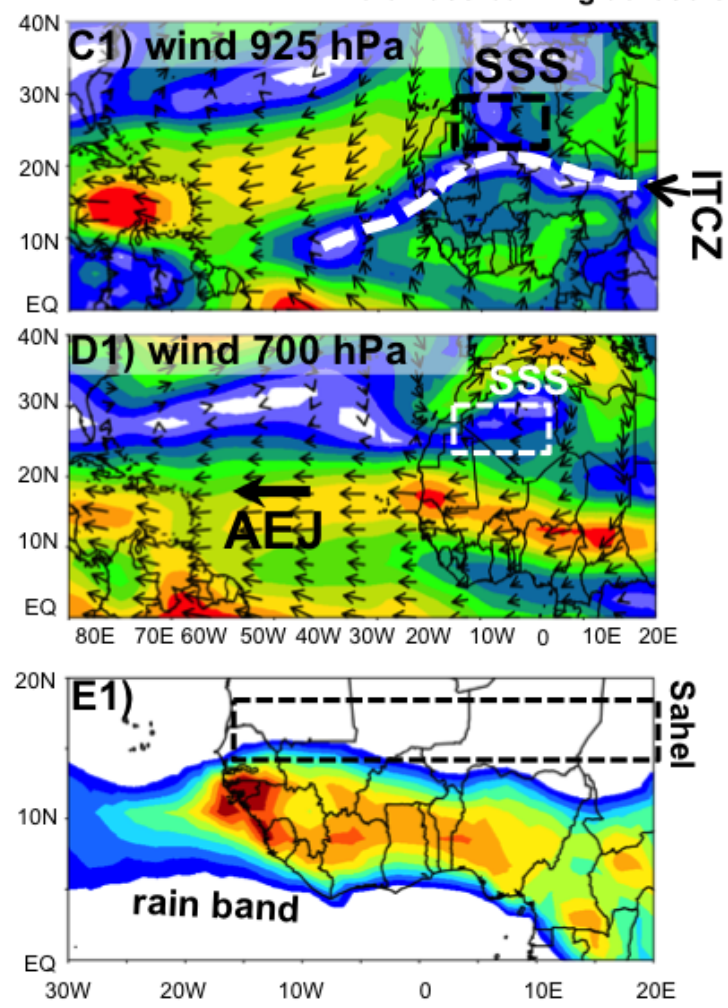

High NAFDI summers

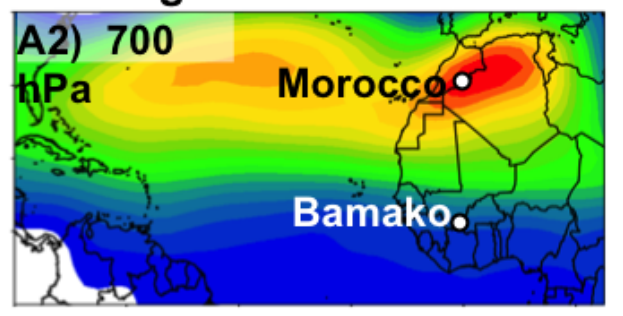

80E 70E 60W 50W 40W 30W 20W 10W 0 10E 20E

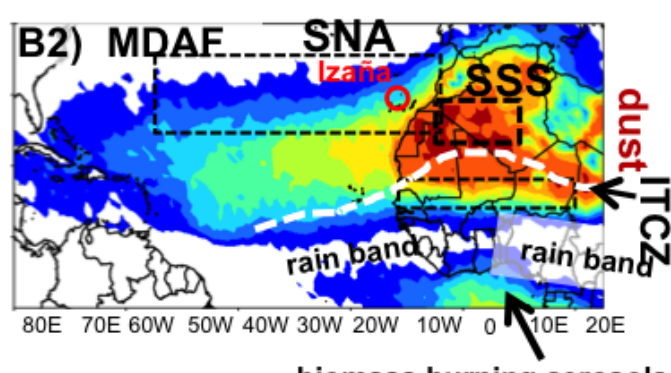

biomass burning aerosols
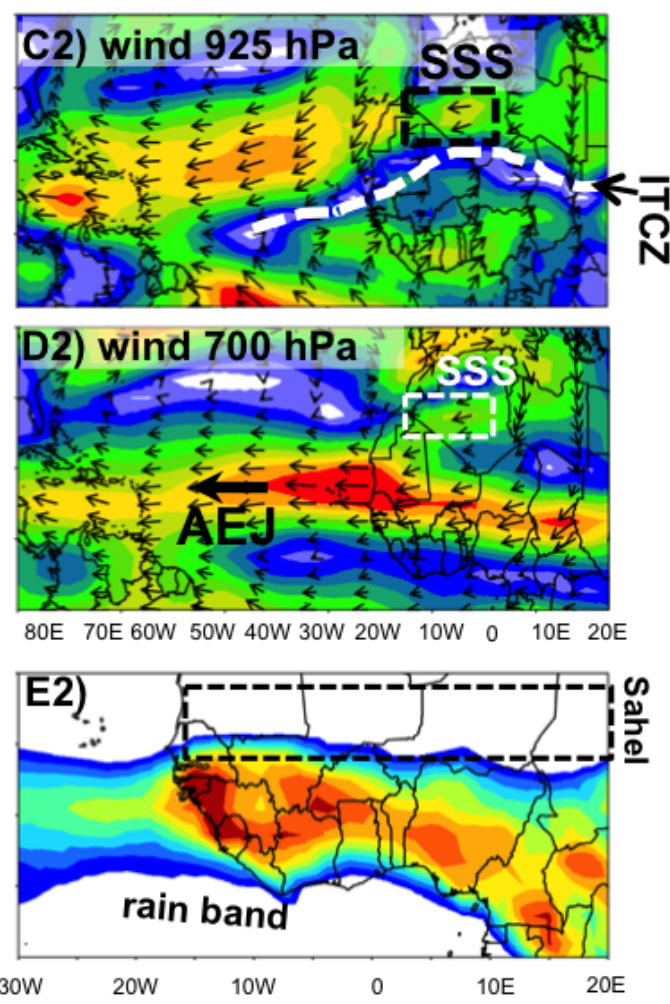
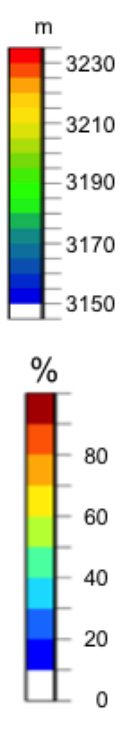

$\mathrm{m} / \mathrm{s}$

Figure 4. North African dipole and spatial distribution of dust and meteorological fields averaged in low and high NAFDI summers. The low NAFDI group includes the summers with the four lowest NAFDI values in the period 1987-2014 (1987, 1996, 1997 and 2006 are -2.79, $-2.04,-3.19$ and -1.54 , respectively). The high NAFDI group includes the summers with the four highest NAFDI values in the period 1987-2014 (1988, 2000, 2008 and 2012 are $+0.68,+0.83,+1.01$ and +2.29 , respectively). Only summers for which satellite AI data are available were considered for this low and high NAFDI summers selection (i.e., 1993-1995 and 2002-2004 were not included). (a) Height of $700 \mathrm{hPa}$ geopotential highlighting the location of the two regions used for determining the NAFDI. (b) MDAF at the north of the rain band (data at the south of the tropical rain band are due to biomass burning aerosols from southern Africa) (Prospero et al., 2002). Mean winds at (c) $925 \mathrm{hPa}(\approx 800 \mathrm{~m}$ a.s.1.) and (d) $700 \mathrm{hPa}(\approx 3000 \mathrm{~m}$ a.s.1.). (e) Mean precipitation rates. The location of the Inter-Tropical Convergence Zone (ITCZ), the subtropical Saharan Stripe (SSS), the African Easterly Jet (AEJ) and the subtropical North Atlantic (SNA) are highlighted. 

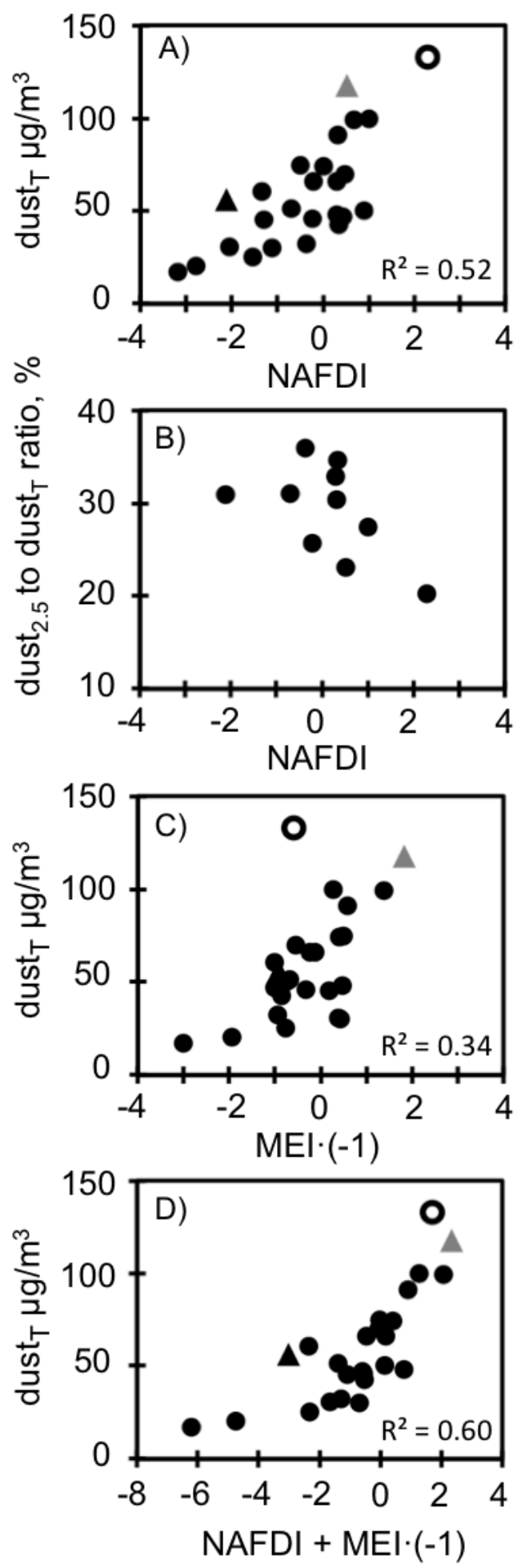

Figure 5. Scatterplot of dust versus NAFDI and MEI. Summer mean dust ${ }_{\mathrm{T}}$ at Izaña (1987-2014) versus NAFDI (a), MEI (c) and $\mathrm{NAFDI}+\mathrm{MEI} \cdot(-1)(\mathbf{d})$, and summer mean dust $_{2.5}$-to-dust - $_{\mathrm{T}}$ ratio (b, 2002-2014) versus NAFDI. Different symbols are used for the summer mean data of 2002 (black triangle), 2010 (grey triangle) and 2012 (white filled symbol) for examining how some data may have different associations with NAFDI and MEI. summer variability in zonal winds in the subtropical Saharan Stripe (Figs. 4c and 6a) and dust export at subtropical latitudes. Reinforcement of easterly winds during high NAFDI summers is also observed in the AEJ (Fig. 4d), which plays a role in the trans-Atlantic dust transport (Jones et al., 2003).

\subsection{Long-term variability of dust size distribution}

Our dust record in two size fractions was used to assess long-term variability in dust size distribution. We found that the NAFDI is correlated with the interannual variability of dust size distribution. Our measurements show pronounced changes in the size distribution of dust particles that are apparently related to wind interannual variability driven by the NAFDI (Fig. 5b). Dust tends to be coarser during high NAFDI years than during low NAFDI years. Observe how the dust 2.5 to dust $\mathrm{T}_{\mathrm{T}}$ ratio tends to decrease with the NAFDI increase: $\sim 30 \%$ in summers with NAFDI $<0$ and down to $\sim 20 \%$ in summers with NAFDI $>2$ (Fig. 5b). The high amount of coarse $(>2.5 \mu \mathrm{m})$ dust during high NAFDI summers may be linked to the activation of dust sources closer to the Atlantic coast and/or faster atmospheric transport due to higher wind speeds. Both processes will reduce the loss rate of larger-size particles due to gravitational deposition during transport (Ryder et al., 2013).

\subsection{Connection of NAFD to climate variability}

In this section we assess if the NAFDI could be used for linking long-term export of Saharan dust with climate variability during the last decades. Here we present some associations between NAFDI, tropical rains and ENSO that will require future investigations.

South of the ITCZ, NAFD is associated with the variability in the tropical monsoon rains. We found that from 1987 to 2014 the interannual variability of the NAFDI is moderately correlated with the precipitation rates over tropical North Africa (Fig. 6c) and with what we defined as the Wet Sahel Portion ( $r=0.54$, Fig. 3d), i.e., the portion of the Sahel region $\left(14-18^{\circ} \mathrm{N}\right.$ to $17^{\circ} \mathrm{W}-22^{\circ} \mathrm{E}$; Fig. $\left.4 \mathrm{e}\right)$ that experienced a precipitation rate $\geq 3 \mathrm{~mm} \mathrm{day}^{-1}$. High NAFDI summers tend to be associated with enhanced precipitation rates in tropical North Africa and northern shifts in the rain bands that may affect the southern Sahel (Figs. 4e1, e2 and 6c). Enhanced dust scavenging in high NAFDI summers may accounts for the negative correlation we observe between the 1987 to 2014 summer mean values of the NAFDI and the MDAF over the Sahel and tropical North Africa (Fig. 6b), in a region where rainfall and mixing between the inland monsoon flow and the SAL may have an influence on spatial and temporal distribution of dust (Canut et al., 2010). The low MDAF in the Sahel and in the tropical rain band during high NAFDI summers, with respect to high NAFDI summers, is also clear in Fig. 4b1 and b2. This is consistent with the negative correlations between Sahelian rains and dust impacts 

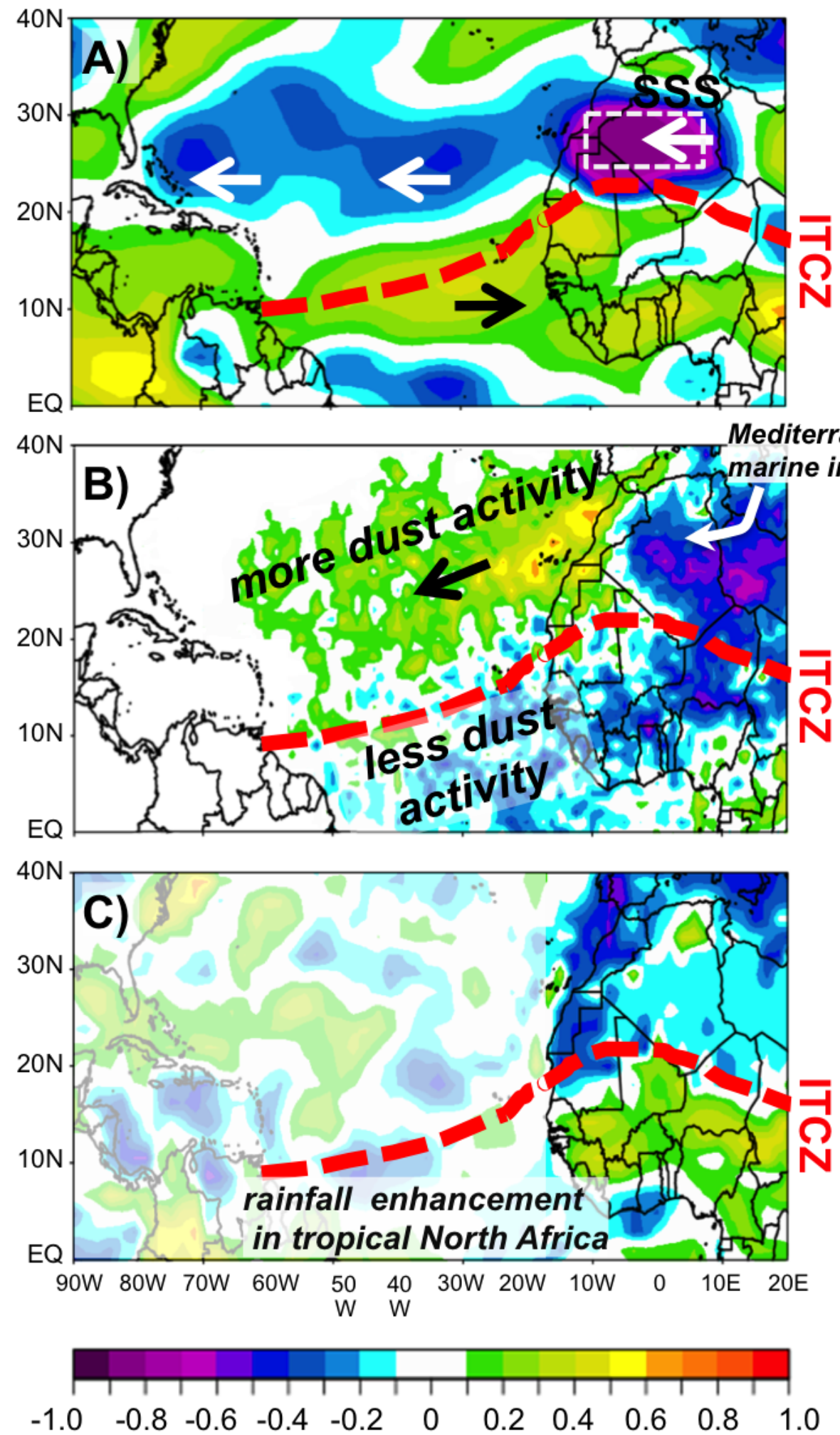

Figure 6. Influence of the NAFD strengthening on zonal winds, spatial distribution of dust and precipitation rate. Correlation coefficient between long-term (1987-2012) summer NAFDI and (a) zonal wind (b) MDAF and (c) precipitation rate. The Inter-Tropical Convergence Zone (ITCZ) and the subtropical Saharan Stripe (SSS) are highlighted. Arrows indicate (a) zonal wind direction and (b) relevant airflows for dust mobilization. 

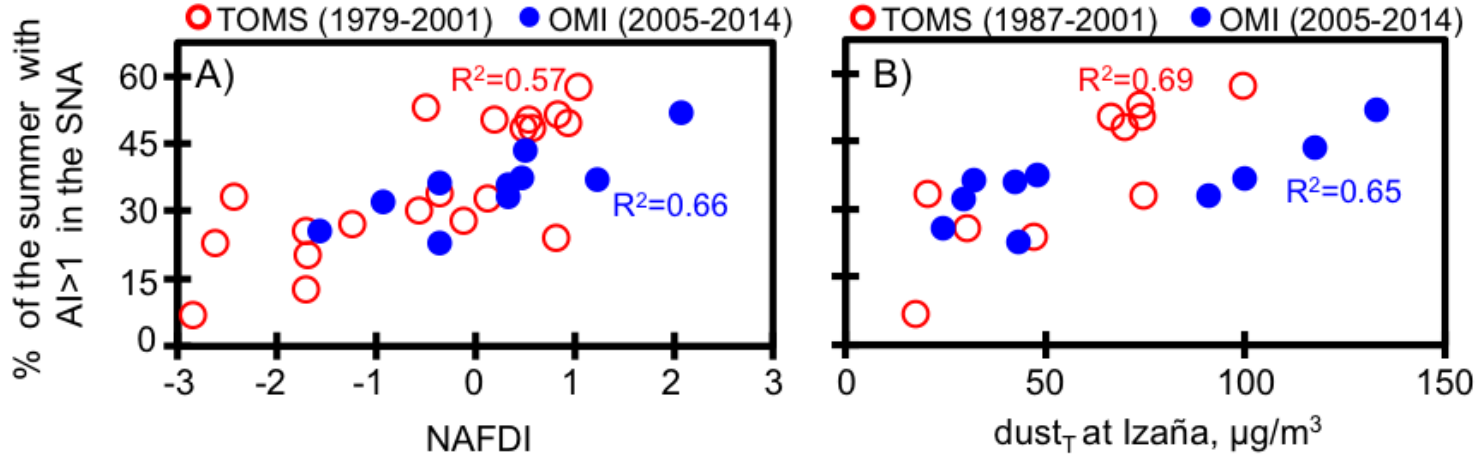

Figure 7. Scatterplot of summer dust activity in the subtropical North Atlantic versus the NAFDI. MDAF in the subtropical North Atlantic (SNA) versus the NAFDI (a) and versus dust T at Izaña (b). Measurements of the TOMS (red circle) and OMI (blue dot) satellite-borne sensors were used. The $R^{2}$ coefficient of the linear fitting is included.

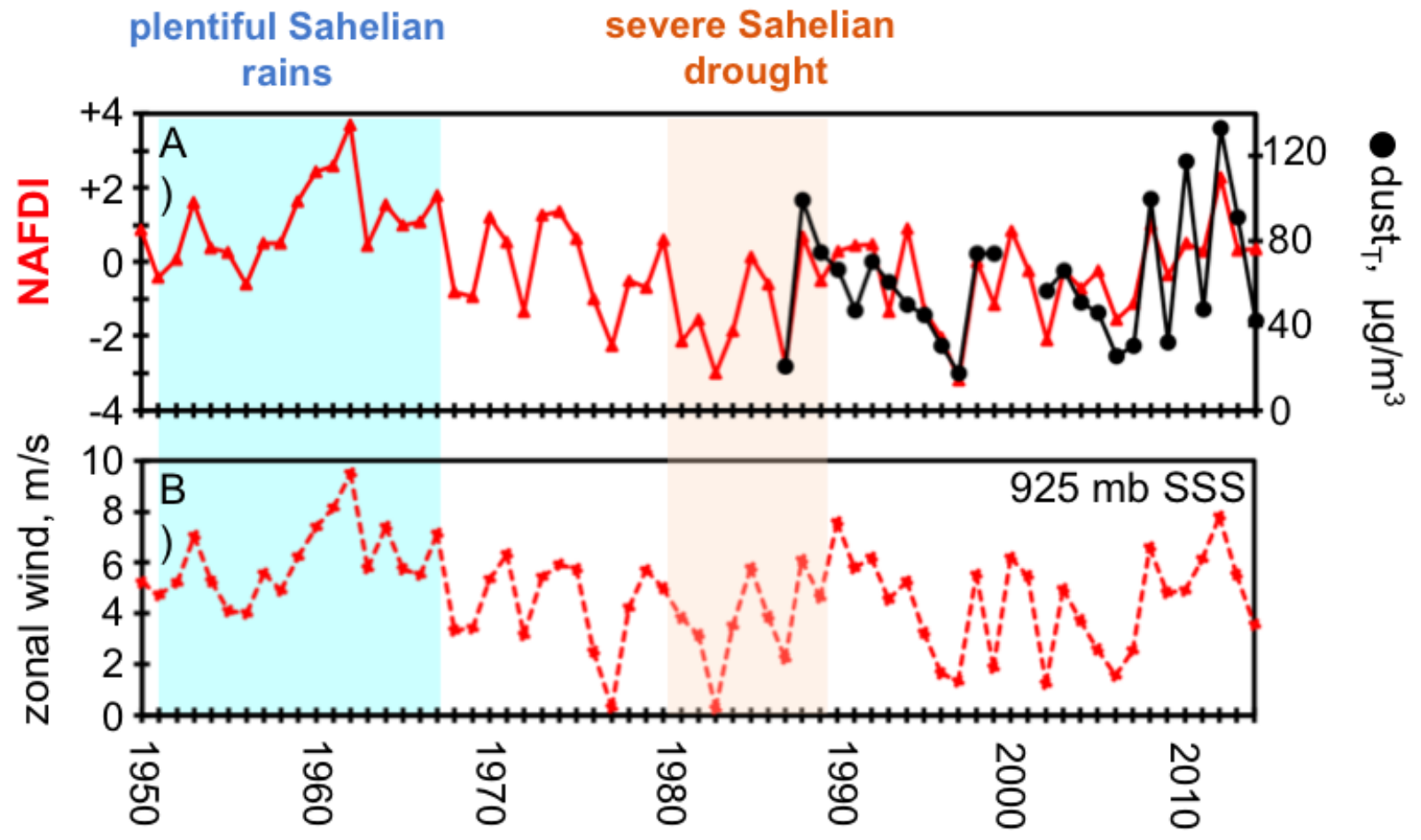

Figure 8. Summer mean values of NAFDI (red triangle, a), dust T at Izaña (black dot, b) and zonal wind at $925 \mathrm{mb}$ in the subtropical Saharan Stripe $\left(25-28^{\circ} \mathrm{N}, 7^{\circ} \mathrm{W}-2^{\circ} \mathrm{E}, \mathbf{b}\right)$. Period of plentiful rains and severe drought in the Sahel are highlighted according to Lucio et al. (2012).

in the Caribbean found by Prospero and Lamb (2003). The long-term (1987-2014) correlation of dust $\mathrm{T}_{\mathrm{T}}$ at Izaña with the Wet Sahel Portion ( $r=0.74$, Fig. 3d) suggests that variability in the Saharan dust export in the subtropical and monsoon tropical rains has been influenced by a common meteorologi$\mathrm{cal} /$ climatic mechanism. Observe how high dust $\mathrm{T}_{\mathrm{T}}$ summers at Izaña have been associated with the high Wet Sahel Portion in the last three decades (e.g., 1988, 1999, 2010, 2012 and 2013, dust T $=75-140 \mu \mathrm{g} \mathrm{m}^{-3}$ and Wet Sahel Portion $=7-$ $15 \%$; Fig. 3d) and vice versa (e.g., 1996, 1997, 2006, 2009, 2011, 2014, dust $\mathrm{T}=17-45 \mu \mathrm{g} \mathrm{m}^{-3}$ and Wet Sahel Portion
$=0.8-4.5 \%$; Fig. $3 \mathrm{~b}$ ). On a shorter timescale (days to weeks), this connection of dust export and monsoon rains was also observed by Wilcox et al. (2010), who found that the tropical rain band shifted northward by 1 to $4^{\circ}$ latitude during westward dust outbreak events accompanied by an acceleration of winds on the northern edge of the AEJ.

We also compared the variability of the NAFDI with that of a set of teleconnection indexes and found that the multivariate ENSO (El Niño-Southern Oscillation) index (MEI) - calculated with sea level pressure, zonal and meridional components of the surface wind, sea surface temperature, 

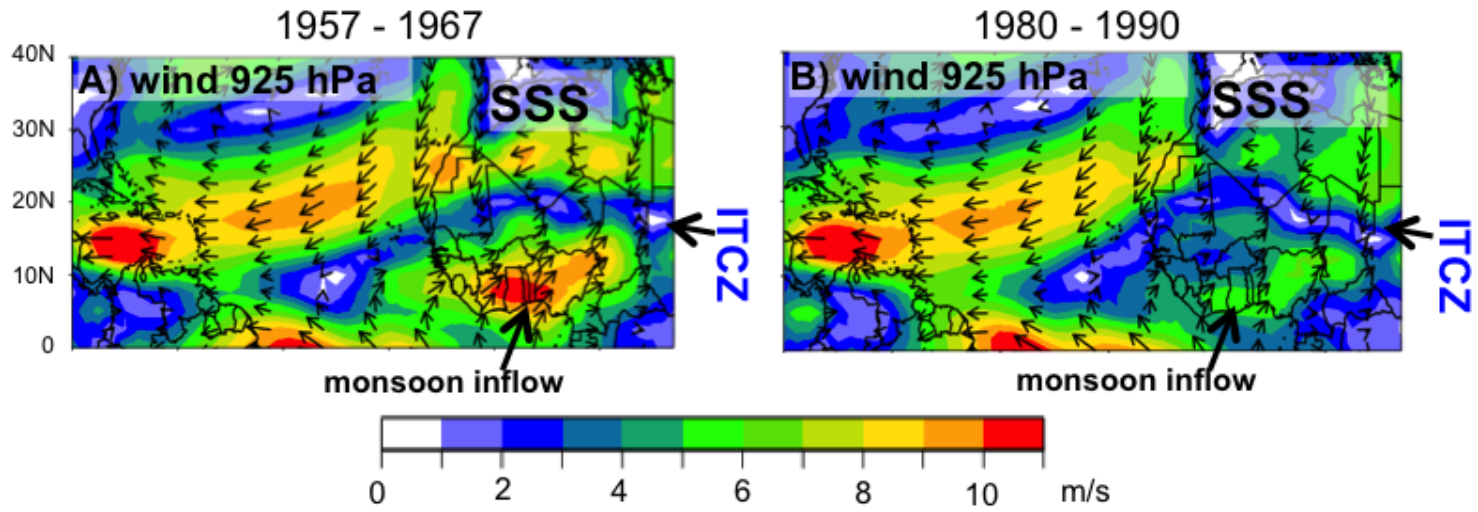

Figure 9. Mean winds at $925 \mathrm{hPa}(\approx 800 \mathrm{~m}$ a.s.1.) in the 1957-1967 (plentiful rains in the Sahel) and 1980-1990 (severe Sahelian drought) decades.

surface air temperature and total cloudiness fraction of the sky over the tropical Pacific Ocean - is moderately correlated with the NAFDI $(r=-0.50)$ and with dust $\mathrm{T}_{\mathrm{T}}$ at Izaña $(-0.59)$ (Fig. 1a) (Table S2 of the Supplement). Because variability in the NAFDI is connected to wind at the north of the ITCZ (Fig. 6a), these correlations suggest that MEI may be teleconnected to winds over the subtropical Sahara, and this would have implications for Saharan dust export. In five of the eight intense ENSO years recorded from 1987 to 2014 (green arrows at the top of Fig. 3), dust $\mathrm{T}_{\mathrm{T}}$ concentrations at Izaña were low (1987, 1997, 2006, 2009 and 2014, 17$32 \mu \mathrm{g} \mathrm{m}^{-3}$; Fig. 3a) coupled with rather low zonal winds at 925 and $700 \mathrm{mb}$ along the subtropical Saharan Stripe (Fig. 3b and c), whereas in the other three intense ENSO years, dust ${ }_{\mathrm{T}}$ concentrations were moderate (1991, 1993 and 2002, 47$61 \mathrm{~g} \mathrm{~m}^{-3}$; Fig. 3a). In the 1987-2014 time series, we can observe that many of the peak dust $\mathrm{T}_{\mathrm{T}}$ summers are associated with correlated increases in NAFDI and MEI - (-1) (e.g., 1988, 1998 and 2008); however, we also observe some peak dust $_{\mathrm{T}}$ summers associated with MEI peaks but rather low NAFDI values (e.g., 2002 and 2010, Fig. 3a) and vice versa, i.e., peak dust $\mathrm{T}_{\mathrm{T}}$ summers associated with NAFDI peaks but rather low MEI values (e.g., 2012). This suggests that NAFDI and MEI may be tracing the dependence of different processes involved in dust export on climate variability (e.g., regional variability in source activation, spatial distribution of dust or altitudinal and latitudinal shifts of the SAL). Observe how long-term summer mean dust $\mathrm{T}_{\mathrm{T}}$ at Izaña exhibits higher linearity with NAFDI + MEI $\cdot(-1)$ (Fig. $5 \mathrm{~d}, R^{2}=$ 0.60 ) than with either the NAFDI (Fig. $5 \mathrm{a}, R^{2}=0.52$ ) or MEI (Fig. 5c, $R^{2}=0.34$ ). The 1987-2014 summer mean dust $_{\mathrm{T}}$ at Izaña exhibited a higher correlation with NAFDI + MEI $\cdot(-1)(r=0.77)$ than with NAFDI $(r=0.72)$ or MEI $\cdot(-1)(r=0.50)$. Teleconnections of dust with several large-scale systems were also observed by Doherty et al. (2008), who found that trans-Atlantic transport of dust was teleconnected to displacement of both the Azores and Hawaiian anticyclones. Deficits in the North African tropical rains have also been linked to ENSO (including summer Palmer, 1986; Bhatt, 1989; Janicot et al., 1996; Rowell, 2001), consistent with the correlation found between the NAFDI and precipitation rates over tropical North Africa (Fig. 6c) and with the low Wet Sahel Portions we observe in low NAFDI and MEI - (-1) summers (Fig. 3a and d). Interannual variability in dust transport in subtropical Asia (Abish and Mohanakumar, 2013) and dust mobilization in sources affected by land use and ephemeral lakes (Ginoux et al., 2012) have also been linked to ENSO.

The increase in the concentrations of dust transported to the tropical North Atlantic - at Barbados - since the mid 1970s has been linked to Sahelian droughts (Prospero and Lamb, 2003). Figure 8a shows the summer NAFDI values from 1950 to 2014. Values of NAFDI were persistently higher prior to the onset of the Sahelian drought - from the 1950s to the mid 1960s - than since the mid 1970s, with the lowest values observed during the most severe part of the drought - from 1980 to 1990 (Fig. 8a). Similarly, summer mean values of zonal wind at $925 \mathrm{mb}$ in the subtropical Saharan Stripe were persistently higher prior to the Sahelian drought (Fig. 8b). This suggests that the meteorological change that occurred in the mid 1970s did not only occur in the Sahel, but also in the subtropical Sahara. Particularly, the high wind speeds in the subtropical Saharan Stripe between the mid 1950s and the mid 1960s (Fig. 9a) - e.g., compared to the 1980-1990 period (Fig. 9b) - may have enhanced dust mobilization in the central Sahara (north of the ITCZ, including the subtropical Saharan Stripe). Further studies should address what the implications have been for dust transport paths and impacts over the North Atlantic of such meteorological changes.

\section{Conclusions}

The analysis of the 1987 to 2014 summer mean values of dust concentrations at Izaña observatory $(\sim 2400 \mathrm{~m}$ a.s.l. in Tener- 
ife) and satellite and meteorological reanalysis data shows that summer Saharan dust export is highly dependent on the variability of the large-scale meteorology in North Africa, which is characterized by a high over the subtropical Sahara and a low over the tropics linked to the monsoon (at $850 \mathrm{hPa}$ and aloft). We referred to this high-low dipole-like pattern as the North African dipole (NAFD) and, in this study, we parameterized its variability in terms of the NAFD intensity (NAFDI): the difference of geopotential height anomalies averaged over the subtropics ( $30-32^{\circ} \mathrm{N}$, Morocco) and the tropics $\left(10-13^{\circ} \mathrm{N}\right.$, Bamako region) close to the Atlantic coast (at $5-8^{\circ} \mathrm{W}$ longitude). Because summer dust export off the coast of North Africa tends to occur between 1 and $5 \mathrm{~km}$ a.s.l., we determined the NAFDI at the $700 \mathrm{hPa}$ standard level. Other parameterizations of the NAFD are plausible, depending on the study subject.

We observe significant summer-to-summer variability in the NAFDI, which is associated with shifts in the Saharan high that have implications for winds over the Sahara and for dust export in the North African outflow. Increases in the NAFDI values (i) result in higher wind speeds at the north of the Inter-Tropical Convergence Zone that are associated with enhanced dust export over the subtropical North Atlantic, (ii) influence the size distribution of exported dust particles (increasing the load of coarse dust) and (iii) are associated with enhanced rain in the tropical and northern shifts of the tropical rain band that may affect the southern Sahel. Variability in the NAFDI is also connected with spatial distribution of dust over the North Atlantic; high NAFDI summers are associated with major winds and dust export in the subtropics and minor dust presence in the tropics (linked to rainfall scavenging), and vice versa.

We found connections of the NAFDI and dust at Izaña with climate variability. El Niño periods (e.g., 1987, 1997, 2006, 2009 and 2014) are generally associated with moderate to low summer mean values of the NAFDI, wind speed at the north of the ITCZ and dust at Izaña, and vice versa during La Niña summers (e.g., 1988, 1998, 1999 and 2010). The 1987-2014 summer mean dust records at Izaña showed a higher correlation with NAFDI + MEI $\cdot(-1)(r=0.77)$ than with either NAFDI $(r=0.72)$ or MEI $\cdot(-1)(r=0.50)$. These correlations show the need for understanding the processes that link dust to climate variability in the subtropics and tropics.

Further studies are necessary to understand how the variability of the summer NAFDI since 1950 to the present day - associated with high wind speeds over subtropical Saharan dust sources prior to the Sahelian drought and low wind speeds over the subtropical Sahara during the severe part of the drought - may have influenced the multi-decadal evolution of the dust export paths.

The Supplement related to this article is available online at doi:10.5194/acp-15-7471-2015-supplement.
Acknowledgements. The Izaña GAW program is funded by AEMET and by the Minister of Economy and Competitiveness of Spain (POLLINDUST, CGL2011-26259). We gratefully acknowledge the cooperation of the NOAA/ESRL Physical Sciences Division, the NASA Goddard Earth Science Data and Information Services Center and the NOAA Air Resources Laboratory. J. M. Prospero's research is supported by NSF grant AGS-0962256. M. I. García holds a grant from the Canarian Agency for Research, Innovation and Information Society and the European Social Fund. We thank our colleague Celia Milford for the comments and suggestions that improved the original manuscript.

Edited by: U. Pöschl

\section{References}

Abish, B. and Mohanakumar, K.: Absorbing aerosol variability over the Indian subcontinent and its increasing dependence on ENSO, Global Planet. Change 106, 13-19, 2013.

Adams, A. M., Prospero, J. M., and Zhang, C.: CALIPSOderived three-dimensional structure of aerosol over the Atlantic Basin and adjacent continents, J. Climate, 25, 6862-6879, doi:10.1175/JCLI-D-11-00672.1, 2012.

Allen, C. J. T. and Washington, R.: The low-level jet dust emission mechanism in the central Sahara: Observations from BordjBadji Mokhtar during the June 2011 Fennec Intensive Observation Period, J. Geophys. Res. Atmos., 119, 2990-3015, doi:10.1002/2013JD020594, 2013.

Andrey, J., Cuevas, E., Parrondo, M. C., Alonso-Pérez, S., Redondas, A., and Gil-Ojeda, M.: Quantification of ozone reductions within the Saharan air layer through a 13-year climatologic analysis of ozone profiles, Atmos. Environ., 84, 28-34, 2014.

Ashpole, I. and Washington, R.: Intraseasonal variability and atmospheric controls on daily dust occurrence frequency over the central and western Sahara during the boreal summer, J. Geophys. Res.-Atmos., 118, 12915-12926, doi:10.1002/2013JD020267, 2013.

Baker, A. R. and Jickells, T. D.: Mineral particle size as a control on aerosol iron solubility, Geophys. Res. Lett., 33, L17608, doi:10.1029/2006GL026557, 2006.

Ben-Ami, Y., Koren, I., and Altaratz, O.: Patterns of North African dust transport over the Atlantic: winter vs. summer, based on CALIPSO first year data, Atmos. Chem. Phys., 9, 7867-7875, doi:10.5194/acp-9-7867-2009, 2009.

Bhatt, U.: Circulation regimes of rainfall anomalies in the African - South Asian monsoon belt, J. Clim., 2, 1133-1144, 1989.

Canut, G., Lothon, M., Saïd, F., and Lohou, F.: Observation of entrainment at the interface between monsoon flow and the Saharan Air Layer, Q. J. Roy. Meteorol. Soc., 136, 34-46, 2010.

Chiapello, I., Moulin, C., and Prospero, J. M.: Understanding the long-term variability of African dust transport across the Atlantic as recorded in both Barbados surface concentrations and large-scale Total Ozone Mapping Spectrometer (TOMS) optical thickness, J. Geophys. Res., 110, D18S10, doi:10.1029/2004JD005132, 2005.

Cowie, S. M., Knippertz, P., and Marsham, J. H.: A climatology of dust emission events from northern Africa using long- 
term surface observations, Atmos. Chem. Phys., 14, 8579-8597, doi:10.5194/acp-14-8579-2014, 2014.

Creamean, J. M., Suski, K. J., Rosenfeld, D., Cazorla, A., DeMott, P. J., Sullivan, R. C., White, A. B., Ralph, F. M., Minnis, P., Comstock, J. M., Tomlinson, J. M., and Prather, K.: Dust and biological aerosols from the Sahara and Asia influence precipitation in the western U.S., Science, 339, 1572-1578, doi:10.1126/science.1227279, 2013.

Cuesta, J., Marsham, J. H., Parker, D. J., and Flamant, C.: Dynamical mechanisms controlling the vertical redistribution of dust and the thermodynamic structure of the West Saharan atmospheric boundary layer during summer, Atmos. Sci. Lett., 10, 34-42, doi:10.1002/asl.207, 2009.

Cuevas, E., Camino, C., Benedetti, A., Basart, S., Terradellas, E., Baldasano, J. M., Morcrette, J. J., Marticorena, B., Goloub, P., Mortier, A., Berjón, A., Hernández, Y., Gil-Ojeda, M., and Schulz, M.: The MACC-II 2007-2008 reanalysis: atmospheric dust evaluation and characterization over northern Africa and the Middle East, Atmos. Chem. Phys., 15, 3991-4024, doi:10.5194/acp-15-3991-2015, 2015.

Delmonte, B., Petit, J. R., Andersen, K. K., Basile-Doelsch, I., Maggi, V. and Lipenkov, V. Y.: Dust size evidence for opposite regional atmospheric circulation changes over east Antarctica during the last climatic transition, Clim. Dyn., 23, 427-438, doi:10.1007/s00382-004-0450-9, 2004.

Díaz, J., Tobías, A., and Linares, C.: Saharan dust and association between particulate matter and case-specific mortality: a casecrossover analysis in Madrid (Spain), Environ. Health, 11, 1-6, doi:10.1186/1476-069X-11-11, 2012.

Doherty, O. M., Riemer, N., and Hameed, S.: Saharan mineral dust transport into the Caribbean: Observed atmospheric controls and trends, J. Geophys. Res., 113, D07211, doi:10.1029/2007JD009171, 2008.

Draxler, R. R. and Rolph, G. D.: HYSPLIT (HYbrid Single-Particle Lagrangian Integrated Trajectory) Model access via NOAA ARL READY Website (http://ready.arl.noaa.gov/HYSPLIT.php) NOAA Air Resources Laboratory, Silver Spring, MD, USA, 2013.

Engelstaedter, S. and Washington, R.: Atmospheric controls on the annual cycle of North African dust, J. Geophys. Res., 112, D17111, doi:10.1029/2006JD007195, 2007.

Fiedler, S., Schepanski, K., Heinold, B., Knippertz, P., and Tegen, I.: Climatology of nocturnal lowlevel jets over North Africa and implications for modeling mineral dust emission, J. Geophys. Res.Atmos., 118, 6100-6121, doi:10.1002/jgrd.50394, 2013.

Flamant, C., Chaboureau, J. P., Parker, D. J., Taylor, C. M., Cammas, J. P., Bock, O., Tim-ouk, F., and Pelon, J.: Airborne observations of the impact of a convective system on the 10 planetary boundary layer thermodynamics and aerosol distribution in the inter-tropical dis- continuity region of the West African Monsoon, Q. J. Roy. Meteor. Soc., 133, 1175-1189, doi:10.1002/qj.97, 2007.

Font-Tullot, I.: Las invasiones de aire caliente africano en el Archipiélago Canario, Revista de Geofísica, Vol. IX, 36, 334-349, 1950.

Forster, P., Ramaswamy, V., Artaxo, P., Berntsen, T., Betts, R., Fahey, D. W., Haywood, J., Lean, J., Lowe, D. C., Myhre, G., Nganga, J., Prinn, R., Raga, G., Schulz, M., and Dorland, R. Van: Climate Change 2007: The Physical Science Basis, Contribution of Working Group I to the Fourth Assessment Report of the Inter- governmental Panel on Climate Change, chap. Changes in Atmospheric Constituents and in Radiative Forcing, Cambridge University Press, Cambridge, UK and New York, NY, USA, 2007.

Ginoux, P., Prospero, J. M., Torres, O., and Chin, M.: Long-term simulation of global dust distribution with the GOCART model: Correlation with North Atlantic Oscillation, Environ. Modell. Softw., 19, 113-128, 2004.

Ginoux, P., Prospero, J. M., Gill, T. E., Hsu, N. C., and Zhao, M.: Global-scale attribution of anthropogenic and natural dust sources and their emission rates based on MODIS Deep Blue aerosol products, Rev. Geophys., 50, RG3005, doi:10.1029/2012RG000388, 2012.

Guirado, C., Cuevas, E., Cachorro, V. E., Toledano, C., AlonsoPérez, S., Bustos, J. J., Basart, S., Romero, P. M., Camino, C., Mimouni, M., Zeudmi, L., Goloub, P., Baldasano, J. M., and de Frutos, A. M.: Aerosol characterization at the Saharan AERONET site Tamanrasset, Atmos. Chem. Phys., 14, 1175311773, doi:10.5194/acp-14-11753-2014, 2014.

Haywood, J. M., Pelon, J., Formenti, P., Bharmal, N., Brooks, M., Capes, G., Chazette, P., Chou, C., Christopher, S., Coe, H., Cuesta, J., Derimian, Y., Desboeufs, K., Greed, G., Harrison, M., Heese, B., Highwood, E. J., Johnson, B., Mallet, M., Marticorena, B., Marsham, J., Milton, S., Myhre, G., Osborne, S. R., Parker, D. J., Rajot, J. L., Schulz, M., Slingo, A., Tanré, D., and Tulet, P.: Overview of the dust and biomassburning experiment and African monsoon multidisciplinary analysis special observing period-0, J. Geophys. Res., 113, D00C17, doi:10.1029/2008JD010077, 2008.

Herman, J. R., Bhartia, P. K., Torres, O., Hsu, C., Seftor, C., and Celarier, E.: Global distribution of UV-absorbing aerosols from Nimbus 7/TOMS data, J. Geophys. Res., 102, 16911-16922, doi:10.1029/96JD03680, 1997.

Hosseinpour, F. and Wilcox, E. M.: Aerosol Interactions with African/Atlantic Climate Dynamics, Environ. Res. Lett., 9, 075004, doi:10.1088/1748-9326/9/7/075004, 2014.

Huneeus, N., Schulz, M., Balkanski, Y., Griesfeller, J., Prospero, J., Kinne, S., Bauer, S., Boucher, O., Chin, M., Dentener, F., Diehl, T., Easter, R., Fillmore, D., Ghan, S., Ginoux, P., Grini, A., Horowitz, L., Koch, D., Krol, M. C., Landing, W., Liu, X., Mahowald, N., Miller, R., Morcrette, J.-J., Myhre, G., Penner, J., Perlwitz, J., Stier, P., Takemura, T., and Zender, C. S.: Global dust model intercomparison in AeroCom phase I, Atmos. Chem. Phys., 11, 7781-7816, doi:10.5194/acp-11-7781-2011, 2011.

Immler, F. and Schrems, O.: Vertical profiles, optical and microphysical properties of Saharan dust layers determined by a ship-borne lidar, Atmos. Chem. Phys., 3, 1353-1364, doi:10.5194/acp-3-1353-2003, 2003.

Janicot, S., Moron, V., and Fontaine, B.: Sahel droughts and ENSO dynamics, Geophys. Res. Lett., 23, 515-518, 1996.

Jickells, T. D., An, Z. S., Andersen, K. K., Baker, A. R., Bergametti, G., Brooks, N., Cao, J. J., Boyd, P. W., Duce, R. A., Hunter, K. A., Kawahata, H., Kubilay, N., laRoche, J., Liss, P. S., Mahowald, N., Prospero, J. M., Ridgwell, A. J., Tegen, I., and Torres, R.: Global iron connections between desert dust, ocean biogeochemistry and climate, Science, 308, 67-71, doi:10.1126/science.1105959, 2005.

Jones, C., Mahowald, N., and Luo, C.: The role of easterly waves on African desert dust transport, J. Climate, 16, 3617-3628, 2003. 
Kalnay, E., Kanamitsu, M., Kistler, R., Collins, W., Deaven, D., Gandin, L., Iredell, M., Saha, S., White, G., Woollen, J., Zhu, Y., Leetmaa, A., Reynolds, R., Chelliah, M., Ebisuzaki, W., Higgins, W., Janowiak, J., Mo, K. C., Ropelewski, C., Wang, J., Jenne, R., and Joseph, D.: The NCEP/NCAR 40-Year Reanalysis Project, B. Am. Meteorol. Soc., 77, 437-471, 1996.

Karyampudi, V., Palm, S., Reagen, J., Fang, H., Grant, W., Hoff, R., Moulin, C., Pierce, H., Torres, O., Browell, E., and Melfi, S.: Validation of the saharan dust plume conceptual model using lidar, Meteosat, and ECMWF data, B. Am. Meteorol. Soc., 80, 10451075, 1999.

Knippertz, P.: Dust emissions in the West African heat trough - The role of the diurnal cycle and of extratropical disturbances, Meteorol. Z., 17, 553-563, 2008.

Knippertz, P., and Todd, M. C.: The central west Saharan dust hot spot and its relation to African easterly waves and extratropical disturbances, J. Geophys. Res., 115, D12117, doi:10.1029/2009JD012819, 2010.

Knippertz, P. and Todd, M. C.: Mineral dust aerosols over the Sahara: Meteorological controls on emission and transport and implications for modeling, Rev. Geophys., 50, RG1007, doi:10.1029/2011RG000362, 2012.

Lafore, J. P., Flamant, C., Giraud, V., Guichard, F., Knippertz, P., Mahfouf, J. F., Mascart, P., and Williams, E. R.: Introduction to the AMMA Special Issue on "Advances in understanding atmospheric processes over West Africa through the AMMA field campaign", Q. J. Roy. Meteorol. Soc., 136, 2-7, 2010.

Lau, K. M., Kim, K. M., Sud, Y. C., and Walker, G. K.: A GCM study of the response of the atmospheric water cycle of West Africa and the Atlantic to Saharan dust radiative forcing, Ann. Geophys., 27, 4023-4037, doi:10.5194/angeo-27-40232009, 2009.

Lavaysse, C., Flamant, C., Janicot, S., Parker, D. J., Lafore, J. P., Sultan, B., and Pelon, J.: Seasonal evolution of the West African heat low: A climatological perspective, Clim. Dynam., 33, 313 330, doi:10.1007/s00382-009-0553-4, 2009.

Lavaysse, C., Flamant, C., and Janicot, S.: Regional-scale convection patterns during strong and weak phases of the Saharan heat low, Atmos. Sci. Lett., 11, 255-264, doi:10.1002/asl.284, 2010a.

Lavaysse, C., Flamant, C., Janicot, S., and Knippertz, P.: Links between African easterly waves, midlatitude circulation and intraseasonal pulsations of the West African heat low, Q. J. Roy. Meteorol. Soc., 136, 141-158, doi:10.1002/qj.555, 2010b.

Li, J., Carlson, B. E., and Lacis, A. A.: A study on the temporal and spatial variability of absorbing aerosols using Total Ozone Mapping Spectrometer and Ozone Monitoring Instrument Aerosol Index data, J. Geophys. Res., 114, D09213, doi:10.1029/2008JD011278, 2009.

Lucio, P. S., Baldicero Molion, L. C., Avila Valadão, C. E., Conde, F. C., Ramos, A. M., and Dias de Melo, M. L.: Dynamical Outlines of the Rainfall Variability and the ITCZ Role over the West Sahel, Atmos. Clim. Sci., 2, 337-350, doi:10.4236/acs.2012.23030, 2012.

Mahowald, N., Albani, S., Kok, J. F., Engelstaeder, S., Scanza, R., Ward, D. S., and Flanner, M. G.: The size distribution of desert dust aerosols and its impact on the Earth system, Aeolian Res., 15, 53-71, 2014.

Mallone, S., Stafoggia, M., Faustini, A., Gobbi, J. P., Marconi, A., and Forastiere, F.: Saharan dust and associations between partic- ulate matter and daily mortality in Rome, Italy, Environ. Health Perspect., 119, 1409-1414, doi:10.1289/ehp.1003026, 2011.

Marsham, J., Parker, D. Grams, C., Taylor, C., and Haywood, J.: Uplift of Saharan dust south of the intertropical discontinuity, J. Geophys. Res., 113, D21102, doi:10.1029/2008JD009844, 2008.

Marticorena, B., Chatenet, B., Rajot, J. L., Traoré, S., Coulibaly, M., Diallo, A., Koné, I., Maman, A., NDiaye, T., and Zakou, A. Temporal variability of mineral dust concentrations over West Africa: analyses of a pluriannual monitoring from the AMMA Sahelian Dust Transect, Atmos. Chem. Phys., 10, 8899-8915, doi:10.5194/acp-10-8899-2010, 2010.

Martínez-García, A., Rosell-Melé, A., Geibert, W., Gersonde, R., Masqué, P., Gaspari, V., and Barbante, C.: Links between iron supply, marine productivity, sea surface temperature, and $\mathrm{CO}_{2}$ over the last 1.1 Ma, Paleoceanography, 24, PA1207, doi:10.1029/2008PA001657, 2009.

Menut, L., Chiapello, I., and Moulin, C.: Predictability of mineral dust concentrations: The African Monsoon Multidisciplinary Analysis first short observation period forecasted with CHIMEREDUST, J. Geophys. Res., 114, D07202, doi:10.1029/2008JD010523, 2009.

Mulitza, S., Heslop, D., Pittauerova, D., Fischer, H. W., Meyer, I., Stuut, J. B., Zabel, M., Mollenhauer, G., Collins, J. A., Kuhnert, H., and Schulz, M.: Increase in African dust flux at the onset of commercial agriculture in the Sahel region, Nature, 466, 226228, doi:10.1038/nature09213, 2010.

Nicholson, S. E.: A revised picture of the structure of the "monsoon" and land ITCZ over West Africa, Clim. Dyn., 32, 11551171, doi:10.1007/s00382-008-0514-3, 2009.

Nicholson, S. E.: The West African Sahel: A Review of Recent Studies on the Rainfall Regime and Its Interannual Variability, ISRN-Meteorology, 2013, 453521, 32, doi:10.1155/2013/453521, 2013.

Otto, S., de Reus, M., Trautmann, T., Thomas, A., Wendisch, M., and Borrmann, S.: Atmospheric radiative effects of an in situ measured Saharan dust plume and the role of large particles, Atmos. Chem. Phys., 7, 4887-4903, doi:10.5194/acp-7-4887-2007, 2007.

Palmer, T.: Influence of the Atlantic, Pacific and Indian oceans on Sahel rainfall, Nature, 322, 251-253, 1986.

Pérez, L., Tobías, A., Querol, X., Künzli, N., Pey, J., Alastuey, A., Viana, M., Valero, N., González-Cabré, M., and Sunyer, J.: Coarse particles from Saharan dust and daily mortality, Epidemiology, 19, 800-807, doi:10.1097/EDE.0b013e31818131cf, 2008.

Pérez García-Pando, C., Stanton, M. C., Diggle, P. J., Trzaska, S., Miller, R. L., Perlwitz, J. P., Baldasano, J. M., Cuevas, E., Ceccato, P., Yaka, P., and Thomson, M. C.: Soil Dust Aerosols and Wind as Predictors of Seasonal Meningitis Incidence in Niger, Environ. Health Perspect., 122, 679-686, doi:10.1289/ehp.1306640, 2014.

Pospichal, B., Karam, D. B., Crewell, S., Flamantb, C., Hünerbein, A., Bock, O., and Saïde, F.: Diurnal cycle of the intertropical discontinuity over West Africa analysed by remote sensing and mesoscale modelling, Q. J. Roy. Meteorol. Soc., 136, 92106, 2010.

Prospero, J. M. and Carlson, T. N.: Vertical and areal distribution of Saharan dust over the western Equatorial North Atlantic Ocean, J. Geophys. Res., 77, 5255-5265, 1972. 
Prospero, J. M. and Lamb, P. J.: African droughts and dust transport to the Caribbean: climate change implications, Science, 302, 1024-1027, doi:10.1126/science.1089915, 2003.

Prospero, J. M., Ginoux, P., Torres, O., Nicholson, S. E., and Gill, T. E.: Environmental characterization of global sources of atmospheric soil dust identified with the Nimbus 7 Total Ozone Mapping Spectrometer (TOMS) absorbing aerosol product, Rev. Geophys., 40, 1-31, doi:10.1029/2000RG000095, 2002.

Prospero, J. M., Collard, F. X., Molinié, J., and Jeannot, A.: Characterizing the annual cycle of African dust transport to the Caribbean Basin and South America and its impact on the environment and air quality, Global Biogeochem. Cy., 28, 757-773, doi:10.1002/2013GB004802, 2014.

Ridley, D. A., Heald, C. L., and Prospero, J. M.: What controls the recent changes in African mineral dust aerosol across the Atlantic?, Atmos. Chem. Phys., 14, 5735-5747, doi:10.5194/acp14-5735-2014, 2014.

Rodríguez, S., Querol, X., Alastuey, A., Kallos, G., and Kakaliagou, O.: Saharan dust contributions to PM10 and TSP levels in Southern and Eastern Spain, Atmos. Environ., 35, 24332447, doi:10.1016/S1352-2310(00)00496-9, 2001.

Rodríguez, S., González, Y., Cuevas, E., Ramos, R., Romero, P. M., Abreu-Afonso, J., and Redondas, A.: Atmospheric nanoparticle observations in the low free troposphere during upward orographic flows at Izaña Mountain Observatory, Atmos. Chem. Phys., 9, 6319-6335, doi:10.5194/acp-9-6319-2009, 2009.

Rodríguez, S., Alastuey, A., Alonso-Pérez, S., Querol, X., Cuevas, E., Abreu-Afonso, J., Viana, M., Pérez, N., Pandolfi, M., and de la Rosa, J.: Transport of desert dust mixed with North African industrial pollutants in the subtropical Saharan Air Layer, Atmos. Chem. Phys., 11, 6663-6685, doi:10.5194/acp-11-66632011, 2011.

Rodríguez, S., Alastuey, A., and Querol, X.: A review of methods for long term in situ characterization of aerosol dust, Aeolian Res., 6, 55-74, doi:10.1016/j.aeolia.2012.07.004, 2012.
Rowell, D.: Teleconnections between the tropical Pacific and the Sahel, Q. J. Roy. Meteorol. Soc., 127, 1683-1706, 2001.

Ryder, C. L., Highwood, E. J., Lai, T. M., Sodemann, H., and Marsham, J. H.: Impact of atmospheric transport on the evolution of microphysical and optical properties of Saharan dust, Geophys. Res. Lett., 40, 2433-2438, doi:10.1002/grl.50482, 2013.

Schepanski, K., Tegen, I., Todd, M. C., Heinold, B., Bönisch, G., Laurent, B., and Macke, A.: Meteorological processes forcing Saharan dust emission inferred from MSG-SEVIRI observations of subdaily dust source activation and numerical models, J. Geophys. Res., 114, D10201, doi:10.1029/2008JD010325, 2009.

Spengler, T. and Smith, R. K.: The dynamics of heat lows over flat terrain, Q. J. Roy. Meteorol. Soc., 134, 2157-2172, 2008.

Tanaka, T. Y. and Chiba, M.: A numerical study of the contribution of dust source regions to the global dust budget, Glob. Planet Change, 52, 88-104, 2006.

Tesche, M., Ansmann, A., Muller, D., Althausen, D., Mattis, I., Heese, B., Freudenthaler, V., Wiegner, M., Esselborn, M., Pisani, G., and Knippertz, P.: Vertical profiling of saharan dust with Raman lidars and airborne HSRL in southern Morocco during SAMUM, Tellus, B61, 144-164, doi:10.1111/j.16000889.2008.00390.x, 2009.

Tsamalis, C., Chédin, A., Pelon, J., and Capelle, V.: The seasonal vertical distribution of the Saharan Air Layer and its modulation by the wind, Atmos. Chem. Phys., 13, 11235-11257, doi:10.5194/acp-13-11235-2013, 2013.

UK Meteorological Office: Weather in the Mediterranean, Vol. I, 2nd Edition, General Meteorology HM Stat, Office, London, 1962.

Welti, A., Lüönd, F., Stetzer, O., and Lohmann, U.: Influence of particle size on the ice nucleating ability of mineral dusts, Atmos. Chem. Phys., 9, 6705-6715, doi:10.5194/acp-9-6705-2009, 2009.

Wilcox, E. M., Lau, K. M., and Kim, K. M.: A northward shift of the North Atlantic Ocean Intertropical Convergence Zone in response to summertime Saharan dust outbreaks, Geophys. Res. Lett., 37, L04804, doi:10.1029/2009GL041774, 2010. 